\title{
Commentary \\ Number needed to treat $=$ six: therapeutic hypothermia following cardiac arrest - an effective and cheap approach to save lives
}

\section{Bernd W Böttiger, Andreas Schneider and Erik Popp}

Department of Anaesthesiology, University of Heidelberg, Germany

Corresponding author: Bernd W Böttiger, bernd.boettiger@med.uni-heidelberg.de

Published: 31 August 2007

This article is online at http://ccforum.com/content/11/4/162

(c) 2007 BioMed Central Ltd

See related research by Pichon et al., http://ccforum.com/content/11/3/R71
Critical Care 2007, 11:162 (doi:10.1186/cc6100)

\begin{abstract}
In 2005, the European Resuscitation Council (ERC) guidelines stated: Unconscious adult patients with spontaneous circulation after out-of-hospital ventricular fibrillation cardiac arrest should be cooled to 32 to $34^{\circ} \mathrm{C}$ for 12 to 24 hours. Patients with cardiac arrest from a non-shockable rhythm, in-hospital patients and children may also benefit from hypothermia. There is no argument to wait. We have to treat the next unconscious cardiac arrest patient with hypothermia.
\end{abstract}

The article "Efficacy of and tolerance to mild induced hypothermia after out-of-hospital cardiac arrest using an endovascular cooling system" by Pichon et al. in the previous issue of Critical Care [1] points to a very relevant health care issue. Only $10 \%$ of patients undergoing out-of-hospital cardiopulmonary resuscitation are discharged alive from the hospital. This high mortality is to a major part due to ischaemic brain damage. In 2002, a European multicentre trial on the use of mild therapeutic hypothermia - as well as other clinical trials - clearly demonstrated a decrease in mortality and a better neurological outcome in cardiac arrest patients $[2,3]$. Only six patients have to be treated to save one life (number needed to treat $=$ six) [4]. This is far better than with most other - expensive - approaches in the intensive care unit (ICU) [5]. Consequently, therapeutic hypothermia has been recommended in an Advisory Statement by the International Liaison Committee on Resuscitation (ILCOR) already in 2003 [6]. In 2005, the European Resuscitation Council (ERC) guidelines stated [7]:

1. Unconscious adult patients with spontaneous circulation after out-of-hospital ventricular fibrillation cardiac arrest should be cooled to 32 to $34^{\circ} \mathrm{C}$. Cooling should be started as soon as possible and continued for at least 12 to 24 hours.
2. Induced hypothermia might also benefit unconscious adult patients with spontaneous circulation after out-ofhospital cardiac arrest from a non-shockable rhythm, or cardiac arrest in hospital.

3. A child who regains a spontaneous circulation but remains comatose after cardiopulmonary arrest may benefit from being cooled to a core temperature of 32 to $34^{\circ} \mathrm{C}$ for 12 to 24 hours.

Therapeutic hypothermia influences postresuscitation brain and other organ - injury in many different ways: it reduces metabolism, free radical formation, intracellular calcium overload, as well as translation and transcription of pathogenic proteins. Additionally, it has anti-apoptotic, anti-inflammatory and anti-coagulatory properties and can reduce oedema formation [8].

There are few areas in emergency and intensive care medicine where scientific evidence is so strong and where international guidelines are so clear. Nevertheless, implementation of hypothermia is lousy. In most countries on both sides of the Atlantic, under 30\% of cardiac arrest patients are receiving hypothermia [9]. The reasons are multifactorial. Colleagues are stating that they do not have enough information and experience, that this therapy is not evidence-based and that it is technically too difficult. Mild therapeutic hypothermia is definitely underused post cardiac arrest, and many patients who need not die are dying because of this clinical reality.

Here, it is very important that independent groups do support implementation of hypothermia. Pichon and colleagues report on the efficacy and tolerance of a commercially available intravascular cooling device used in 40 post cardiac arrest patients [1]. Cooling with this device was safe, relatively fast 
and effective in maintaining the targeted temperature. Regardless of the initial cardiac rhythm - about which the brain does not care - all patient groups benefited from cooling with this device. There are no clinical trials available yet which compare outcome after different cooling techniques. Clear recommendations for a specific method are thus not possible. Maintenance of hypothermia is practicable with both surface and endovascular cooling. In the past, feedback mechanisms have been more sophisticated with endovascular cooling devices. Very recent data on different techniques of body surface cooling suggest that these techniques are also able to maintain body temperature in a clinically sufficient way [10].

Animal experimental data suggest that hypothermia is more effective the faster it is established after the arrest [11]. Even the five hours needed in the present study may be long. Therefore, the use of other and faster methods to induce hypothermia must be considered. Infusion of ice-cold Ringer's solution (30 ml/kg within 30 minutes) has been shown to be an easy, cheap, effective and safe way of inducing hypothermia in less than one hour [12]. This is even possible in the out-of-hospital setting [13]. For subsequent maintenance of hypothermia, intravascular and body surface cooling techniques may both be effective and safe.

Well known side effects of therapeutic hypothermia, like hypokalaemia, hypomagnesaemia and bacteraemia may occur, and it is important to know this. Major complications including arrhythmias, bleeding, pneumonia, sepsis et cetera, however, do not occur more often in hypothermic as compared to normothermic cardiac arrest patients $[2,3]$. The most important 'side effect' of hypothermia is that it is not used routinely in most cardiac arrest patients. There is no good argument to wait any longer. According to Hippocrates, we have to treat the next unconscious cardiac arrest patient with mild therapeutic hypothermia, regardless of which technique we are using.

\section{Competing interests}

The author(s) declare that they have no competing interests.

\section{References}

1. Pichon N, Amiel JB, Francois B, Dugard A, Etchecopar C, Vignon $P$ : Efficacy of and tolerance to mild induced hypothermia after out-of-hospital cardiac arrest using an endovascular cooling system. Crit Care 2007, 11:R71.

2. Bernard SA, Gray TW, Buist MD, Jones BM, Silvester W, Gutteridge G, Smith K: Treatment of comatose survivors of out-ofhospital cardiac arrest with induced hypothermia. $N$ Engl $J$ Med 2002, 346:557-563.

3. Hypothermia after Cardiac Arrest Study Group: Mild therapeutic hypothermia to improve the neurologic outcome after cardiac arrest. N Engl J Med 2002, 346:549-556.

4. Holzer M, Bernard SA, Hachimi-Idrissi S, Roine RO, Sterz F, Müllner M: Hypothermia for neuroprotection after cardiac arrest: systematic review and individual patient data metaanalysis. Crit Care Med 2005, 33:414-418.

5. Bernard GR: Drotrecogin alfa (activated) (recombinant human activated protein $\mathrm{C}$ ) for the treatment of severe sepsis. Crit Care Med 2003, 31:S85-S93.
6. International Liason Committee on Resuscitation: Therapeutic hypothermia after cardiac arrest. An advisory statement by the Advancement Life support Task Force of the International Liaison committee on Resuscitation. Resuscitation 2003, 57: 231-235.

7. European Resuscitation Council: European Resuscitation Council guidelines for resuscitation 2005. Resuscitation 2005, 67:S1-S189.

8. Popp E, Böttiger BW: Cerebral resuscitation: state of the art, experimental approaches and clinical perspectives. Neurol Clin 2006, 24:73-87.

9. Merchant RM, Soar J, Skrifvars MB, Silfvast T, Edelson DP, Ahmad F, Huang KN, Khan M, Vanden Hoek TL, Becker LB, Abella BS: Therapeutic hypothermia utilization among physicians after resuscitation from cardiac arrest. Crit Care Med 2006, 34:1935-1940.

10. Haugk M, Sterz F, Grassberger M, Uray T, Kliegel A, Janata A Richling N, Herkner H, Laggner AN: Feasibility and efficacy of a new non-invasive surface cooling device in post-resuscitation intensive care medicine. Resuscitation 2007, in press.

11. Kuboyama K, Safar P, Radovsky A, Tisherman SA, Stezoski SW, Alexander $\mathrm{H}$ : Delay in cooling negates the beneficial effect of mild resuscitative cerebral hypothermia after cardiac arrest in dogs: a prospective, randomized study. Crit Care Med 1993, 21:1348-1358.

12. Bernard S, Buist M, Monteiro O, Smith K: Induced hypothermia using large volume, ice-cold intravenous fluid in comatose survivors of out-of-hospital cardiac arrest: a preliminary report. Resuscitation 2003, 56:9-13.

13. Virkkunen I, Yli-Hankala A, Silfvast T: Induction of therapeutic hypothermia after cardiac arrest in prehospital patients using ice-cold Ringer's solution: a pilot study. Resuscitation 2004, 62:299-302. 